This item was submitted to Loughborough's Research Repository by the author.

Items in Figshare are protected by copyright, with all rights reserved, unless otherwise indicated.

\title{
Contestations of feminism, secularism and religion in the West: the discursive othering of religious and secular women
}

\section{PLEASE CITE THE PUBLISHED VERSION}

https://www.idunn.no/nordic_journal_of_religion_and_society/2019/01

\section{PUBLISHER}

Universitetsforlaget

VERSION

AM (Accepted Manuscript)

\section{PUBLISHER STATEMENT}

This work is made available according to the conditions of the Creative Commons Attribution-NonCommercialNoDerivatives 4.0 International (CC BY-NC-ND 4.0) licence. Full details of this licence are available at: https://creativecommons.org/licenses/by-nc-nd/4.0/

\section{LICENCE}

CC BY-NC-ND 4.0

\section{REPOSITORY RECORD}

Nyhagen, Line. 2019. "Contestations of Feminism, Secularism and Religion in the West: The Discursive Othering of Religious and Secular Women”. figshare. https://hdl.handle.net/2134/36957. 
Contestations of Feminism, Secularism and Religion in the West: The Discursive Othering of Religious and Secular Women

Line Nyhagen, Loughborough University, United Kingdom.

\section{Abstract}

Secular and religious women have a history of fighting for women's rights and gender equality. Yet, contemporary feminist and women's movements in the West are largely understood as secular, and as rejecting religion, and religion is often perceived as the antithesis of empowerment and emancipation. In this article I problematise the relationship between feminism, secularism and religion via a discussion of secular feminist views on women and religion, and religious women's views on secular feminism. Bringing together previously separate strands of work, this article provides an original analysis of how both secular feminist women and non-feminist religious women engage in discursive articulations of Othering, constructing inferior subjects who are (dis-)placed outside the boundary of 'women like us'. Such discursive representations, which are rooted in perceptions of feminism and religion as unitary and static, contribute to the construction and maintenance of sharp boundaries between secular and religious women, thus hindering the potential for dialogue and collaboration in support of women's rights and gender equality. 
Contestations of Feminism, Secularism and Religion in the West: The Discursive Othering of Religious and Secular Women

\section{Introduction}

Contemporary debates about religion, secularism and gender equality in the West are infused with narratives of linear progression from darkness to light, where religion constitutes irrationality and backwardness and secularism is imbued with rationality and progress. Moreover, gender inequality is associated with religion and gender equality is tied to the secular (Jakobsen and Pellegrini 2008). Within this binary discursive framework, described by Taylor $(2011,52)$ as 'the myth of Enlightenment', increasing secularisation is postulated as leading to growing gender equality, via an agentic analysis where the secular individual, and also the secular state, represent reason, rationality, progress, choice and agency. In contrast, religion is approached from a structural perspective that portrays religious subjectivities as dominated and oppressed, while religious states are viewed as innately oppressive. It follows that secularism as a political-ideological project has the capability to 'liberate women' from the burden of religion, while religion as ideology is destined to always oppress. This binary, static analysis of religion and secularism in relation to gender is particularly prominent among anti-religious feminist scholars and constituencies of feminist activists who singularly attribute oppressive (versus emancipatory) power to religion. The binary has come under increasing attack, however, by secular and religious feminist scholars who note that religion and secularism both have the capacity to support gender inequality and equality (Aune, Sharma and Vincett 2008, Braidotti 2008, Cady and Fessenden 2013, Jakobsen and Pellegrini 2008, Mahmood 2005, Phillips 2016, Reilly 2017, Scott 2018). As do secular women, religious women have a complex relationship with 'gender equality' and 'feminism'. Neither all religious women nor all secular women identify with 'feminism', 
and not all are concerned with 'gender equality'. Moreover, these very terms are highly contested, as evidenced by the disunity and dissonance that have often characterised women's movements (Nyhagen and Halsaa 2012). While religious feminists accept the notion that religion can be used to justify and maintain discrimination against women, they reject the claim that religions are necessarily patriarchal. Religious feminists such as King (2004), Plaskow (1990) and Wadud (1999), to name but a few, have chosen a route of engagement with their own religious tradition in an attempt to change gendered practices from within, thus seeking to reconcile religious faith with feminist beliefs. Scholarly knowledge about how 'ordinary' or 'lay' religious women view and/or engage with gender equality and feminism is, however, scarce (see Aune 2014, Nyhagen and Halsaa 2016).

In this context of contestation and debate between secularism, religion and feminism, we need to interrogate secular views on religion and gender, and religious views on gender and the secular. Secular and religious discourses on gender vary 'internally' as well as across the binary divide, and it is important to examine and understand their variety and differences. In this article I bring together, analyse and compare two previously separate strands of empirical work (Nyhagen 2017, Nyhagen and Halsaa 2016) via an innovative application of the analytical framework of discursive Othering. As Pickering $(2001,72)$ argues, '[t]he symbolically constructed Other and the patterns of social exclusion and incorporation entailed by it are distributed in sign and language, discourse and representation'. As a form of discursive representation of groups, Othering constructs differences between 'us' and 'them', assigning superior status to 'us' and inferior status to 'them' (Hall 1997, 258). While the Other is 'apparently all-determined', 'we' are uniquely individual (Pickering 2001, 74). Such discursive acts of othering, which are intimately linked to 'intersecting forms of power and powerlessness' (Wilkinson and Kitzinger 1996, 16), are themselves rendered invisible by the appearance of the constructed differences as 'natural' or obvious (Pickering 2001, 70). 
Generally, neither feminist nor religious women are associated with hegemonic forms of political-institutional power. It could be argued that most women are relatively less powerful than most men, and that some women are relatively more powerful than some women. While 'there are many dimensions of power and powerlessness along which Otherness can be constructed' (Kitzinger and Wilkinson 1996, 15), the discursive power of particular representations differs, depending on the context in which they are uttered, in what ways and by whom, and the extent to which they resonate with existing hegemonic forms of representation and power. Discourses of Othering can be invoked by powerful and marginalized individuals, groups and institutions; they can hinder mutual understanding and dialogue, and as such undermine the potential formation of strategic political alliance in support of social justice.

By analysing and discussing examples of discursive engagements by secular feminist women (scholarly and political statements) and non-feminist religious women (research interviews), I demonstrate how different women partake in discourses of Othering which, respectively, represents either religious women as the Other, or feminist women as the Other. I discuss how academic and political writings of secular feminists in the West (the feminist scholar Sheila Jeffreys and select women's organisations in Europe) construct religious women as the Other by invoking a binary framework between religion and the secular and forwarding a singular view of religion as patriarchal and oppressive to women. I also show how nonfeminist religious women (interviewed Christian and Muslim women in Europe) engage in a discursive Othering of secular feminists by associating feminism with man-hating, political lesbianism, materialism and selfishness. I do not wish to argue that discursive representations of the Other which are forwarded via individual feminist academic scholarship, collective feminist political claims-making and individual research interviews have comparable status or impact. Instead, I use examples from these different types of discursive representation in 
an attempt to 'destabilize' and 'interrupt' narratives of Othering (Kitzinger and Wilkinson $1996,10)$ that also resonate with broader, societal representations of religion (Nussbaum 2012, Scott 2018) and of feminism (Walby 2011).

\section{The Need for Context-Specific Approaches to Religion, Secularism and Feminism}

Are feminism and religion (in)compatible? Is feminism necessarily tied to secularism, or is it possible to advocate a religious feminism? These questions have both normative and empirical aspects, addressing whether feminism, secularism and religion can or should be linked, and also where and how feminism, secularism and religion have been intertwined in historical and contemporary forms of social activism. As noted, the relationship between feminism, secularism and religion is debated by feminist scholars and activists alike, and academic discussions often start with attempts to define the terms involved, despite openly acknowledged difficulties in defining what 'feminism', 'religion' and 'secularism' is (see, e.g., Jeffreys 2012, Zwissler 2012, King 2004, Castelli 2001, Kosmin 2007, Laborde 2017). Feminism, religion and secularism all involve beliefs, which are contested and negotiated both within and outside particular groups. The beliefs also vary across time and space. Feminist ideologies range from liberal to radical and Marxist-Socialist approaches, to name a few. Notably, the term 'feminism' is not embraced by all who work to promote gender equality. Moreover, feminists impart differing views on what constitutes 'gender equality' as well as varying rationales for why gender equality is just (see Offen 1988). Attempts to formulate universal definitions of feminism have been critiqued as they tend to prioritise gender and overlook intersections between multiple identity markers and structural inequalities including class, race and sexuality. Similarly, Beckford (2003) argues that attempts to provide universal definitions of religion, including of what religion is or what 
religion does, should be abandoned in favour of 'map[ing] the varieties of meaning attributed to religion in social settings' (Beckford 2003, 20). Scott $(2018,14)$, moreover, shows that the meaning of 'secularism' has shifted over time and argues that, today, it has 'become synonymous with (an ill-defined) gender equality that distinguishes West from the East, the Christian secular from the Islamic'.

Despite the prevalence of religious belief and practice among women (Pew Research Center, 2016), religion (including the work of religious feminists, women's participation in religious organisations, and the role of religion in women's everyday lives) has been marginalised in Western feminist scholarship. In this regard, Žarkov $(2015,5-6)$ argues that 'the role of faith in women's everyday life [has] often [been] ignored, even more often seen as a symbol of traditionalism and backwardness, an obstacle to emancipation, and seldom recognized as an inspiration in women's struggle for social justice and women's rights'. King $(2004,196)$ goes further and argues that 'without religion and spirituality, feminism will lack an essential dimension and source of empowerment'. While extant scholarship has to some extent recognised the contributions of religious women to the so-called first wave women's movements (e.g., Braude 2001, McFadden 1999), there is a lack of research on more recent forms of activism among religious women in Europe and beyond (Aune and Nyhagen 2016), including second- (Braude 2004) and third-wave feminist movements (Llewellyn and Trzebiatowska 2013; for some case studies, however, see Nyhagen 2017). Broadly speaking, feminist mobilization, activism and claims-making from the 1960s and onwards has predominantly been understood by as secular. Braidotti $(2008,7)$, for example, who acknowledges a religion-positive tradition within feminism which she labels the 'nonsecularists', also argues that most European feminists have been and are secular. Similarly, Žarkov $(2015,5)$ states that ' ... mainstream Western feminism has to a large extent adopted secularism'. This is supported by Jeffreys $(2012,15-16)$, who claims that 'all major feminist 
theorists' of the 1970s and 1980s rejected religion as they 'saw religion as crucial' to women's subordination. Notably, these views are challenged by feminist scholars who argue that religion has either been overlooked or treated negatively in 'women's movement histories and feminist texts' (Aune 2014, 3; see also Llewellyn and Trzebiatowska 2013). Further research on religious women's diverse mobilization and activism is therefore needed before we can safely conclude that 'Western feminism' is predominantly secular. In research, the definitions and boundaries we invoke about what constitutes feminist activism are crucial, as they can limit or expand the stakeholders, types and sites of activism we study (Nyhagen Predelli 2012). As Ferree (2006) also argues, different constituencies work to promote 'women's concerns' in multiple and diverse contexts. Religious and secular women's activism takes place in a multitude of sites and spaces, including within and outside explicitly religious and secular organizations, and within and outside women's movement and feminist organizations. Moreover, whether, when and how women invoke religion or secularism as a basis for their activism is an empirical question, and to best capture women's activism in specific contexts we need an intersectional lens that does not prima facie privilege gender. Women's struggles for justice span a broad range of issues, some of which deal explicitly with gender equality and others which may give priority to anti-racism, poverty, peace efforts or the environment. Importantly, the latter may also 'develop an interest in changing gender relations' (Ferree 2006, 6).

\section{Theorizing the diversity of secular feminist stances on religion}

Rather than positing a dichotomy between the religious and the secular, recent scholarly interventions suggest that they are intertwined in complex ways (see, e.g., Cady and Fessenden 2013). Moreover, neither 'religion' nor 'secularism' are unitary and static phenomena; their expressions and representations change over time and across space. It is 
useful to distinguish between different forms of secularism. I follow Kosmin's understanding of 'secular' as 'a world-view, a system of beliefs, or a modality of sense-making that is determinedly non-religious' (Kosmin 2007, 6). Secularism, on the other hand, is a 'political discourse' (Scott 2018,9) that proposes some kind of normative statement about the role of religion in society and vis-à-vis the state. Inspired by Kosmin (2007), who proposes a continuum from hard to soft versions of secularism, I have previously suggested that feminist forms of secularism can be articulated in at least three ways: a 'hard' secular position that is hostile to all forms of religion in both the private and public spheres; a 'mixed hard and soft' stance that accepts religion in the private sphere but is hostile towards religion in the public sphere; and a 'soft' approach that accommodates religion in both the private and public spheres (Nyhagen 2017). In this article, I discuss how both the 'mixed' and 'hard' positions contribute to the discursive Othering of religious women. Only the 'soft' position enables a deconstruction of differences and boundaries between religious and secular women. From a 'hard' secular feminist perspective, religion is a patriarchal system of institutionally defined beliefs that inevitably oppresses women (see, e.g., Okin 1999 and Jeffreys 2012), and as such it has no place in the public sphere nor in the lives of 'emancipated' women. This Marxist-inspired analysis suggests that religion 'is little more than a bag of superstitions' ultimately aimed at controlling women (Nussbaum 1999, 105), and that any political claimsmaking rooted in religion is illegitimate. In this view, only secular beliefs and a secular state are capable of supporting and defending women's rights and gender equality. A 'mixed hard and soft' secular feminist approach, on the other hand, concedes that religion may provide a source of meaning and identity for individuals and groups and as such plays an important role in people's private lives. In so doing, it echoes a Weberian analysis of the meaning, purpose and sense of community that religion can provide to individuals. However, the mixed perspective also argues that religion belongs in the private sphere; it must not interfere with 
the state and the broader public sphere. It also views religious institutions as patriarchal and as posing threats to women's rights and gender equality. Finally, a 'soft' feminist view acknowledges the importance of religion as a source of meaning and identity for individuals whilst also recognising that religion is inherently 'communicative and public' (Woodhead 2013, 96). It accepts that religion may give people a sense 'of moral direction, of conviction, of belonging' that is ultimately social (ibid.), and affords legitimacy to political claimsmaking rooted in religious convictions. The soft approach concedes that when religious subjects partake in political deliberation they cannot reasonably be expected to leave their faith at their doorstep, and that they have a legitimate claim to recognition from, and participatory parity with, secular stakeholders (Fraser 2007; see also Taylor 2011, Phillips 2016). The soft feminist secular perspective acknowledges that neither a religious nor a secular state can guarantee gender equality; either may function in oppressive and/or emancipatory ways (see, e.g., Scott 2018). ${ }^{i}$ It argues that, while religion may be used to justify the oppression of women, it may also 'contribute to the struggle for justice', including the struggle for gender equality (Nussbaum 1999, 107).

\section{Secular feminist women's discursive representations of religion and gender}

In this section I discuss select empirical examples of discursive representations of women and religion by secular feminist stakeholders including the academic scholar Sheila Jeffreys, the UK-based organisations Women Against Fundamentalism and Southall Black Sisters, and the European organisation The European Women's Lobby; the latter of which has explicitly linked its views on women and religion to that of Council of Europe, a democratic European interparliamentary institution. The aim is two-fold: to discuss secular feminist representations of women and religion in political claims-making ranging from feminist scholars and 
women's movement organisations to public democratic institutions, and to discuss the engagement of such stakeholders in the discursive Othering of religious women.

The Western feminist scholar Sheila Jeffreys rejects religion as inevitably patriarchal and proposes a universal and permanent conflict between 'women's rights' and 'religious rights'. In Jeffreys' view, 'the subordination of all women is the bedrock of all religions', and 'all religions are dangerous to women's rights' (Jeffreys 2012, 32 and 4) due to the harm caused to women from a range of social practices carried out in the name of religion, ranging from veiling to polygamy, forced marriage and genital mutilation. In Jeffrey’s Marxist analysis, all functions of religion are negative; religion cannot positively contribute to social change. Moreover, Jeffrey foregrounds a structural approach where Christianity, Judaism and Islam are portrayed as internally coherent, unitary and powerful systems that exercise power and control over their adherents. Religious women are viewed as forced into patriarchal submission by male-dominated religious structures, and therefore as lacking in agency. Religious women thus need to be liberated by becoming secular, and only a secular state is viewed as capable of securing women's equality (ibid., 191). Jeffreys sees great harm in including religious people and religious organizations in democratic deliberation, and suggests that 'religions $[\ldots]$ are unsuitable partners for governments that purport to be committed to equal opportunities for women' (Jeffreys 2011, 370). Furthermore, Jeffreys describes feminist ideas as built on atheism and states that 'disrespect' for religion is 'the natural amniotic fluid of feminist thought and activism' (Jeffreys 2012, 5). In these discursive representations, Jeffreys forwards a hard secular feminism, constructing a strict demarcation between religion and the secular. Religious women are portrayed as a homogenous group of victimized, inferior Others, in stark contrast to individual, liberated and superior secular women. In effect, this Othering is 'a denial of [religious women's] right to name and define themselves' and 'a denial of their humanity' (Pickering 2001, 73). 
Secular feminist discourses that in various ways represent religious women as the Other is also manifest in diverse Western feminist activist contexts outside the academia, of which I now turn to some examples. Women Against Fundamentalism (WAF) was established in London in 1989 as a reaction against the so-called 'Rushdie affair', in which novelist Salman Rushdie was issued with a religious fatwa after the publication of the novel The Satanic Verses. Secular and religious women mobilized together in WAF activism, calling for resistance to all forms of religious fundamentalism and 'for a secular state' (Dhaliwal and Yuval-Davis 2014, 9). Collaborating with groups such as Catholics for Free Choice and Women Living Under Muslim Laws, WAF thus confirmed that religious and secular women can have common interests. WAF initially represented a mixed hard and soft secular feminist discourse which made such collaborations possible. On the one hand, religious belief and practice were presented as 'as a matter of individual choice' (Dhaliwal and Yuval-Davis 2014,9 ), which meant a recognition of the value of religious belief in the lives of many women, including those active in WAF, whilst also relegating religion to the private sphere. While WAF initially acknowledged that 'religion can play a progressive, political role' (WAF 1996, 1), its main focus was on aspects of religion considered oppressive to women, and the organization insisted that only a secular state could safeguard women's interests. It argued against any form of interference in politics and public affairs by religious stakeholders, thus effectively denying the legitimacy of political claims-making rooted in religious convictions. Although WAF recognized individuals' religious faith in the private domain, an insistence on secularism in the public sphere effectively denied religious subjects 'expert status either on their own lives or on that of the dominant group' (Kitzinger and Wilkinson 1996, 9). The construction of 'religion' as illegitimate in political deliberation meant that religious subjects were in effect marked as inferior Others and relegated to a position of powerlessness. For religious women within WAF, on the other hand, their faith 
identities, as well as their gender (and for some, also their ethnic minority status), provided meaning and belonging and directly inspired their community activism. Disparate views on whether religion and/or secularism should inform and inspire struggles for social justice ultimately led to unresolved tensions (Dhaliwal and Yuval-Davis 2014, Pearson 2014, Balchin 2014), and WAF folded in 2012.

Pre-dating WAF by ten years is the secular feminist organization Southall Black Sisters (SBS), founded in London in 1979, which has advocated a hard feminist secular position on women and religion. Similar to Jeffreys (2012), feminist activist Hannaha Siddiqui, who joined SBS in 1987, has stated that 'all religions are oppressive to women; they regard women as inferior, subject to control of male members of the family' (Siddiqui 1991, 80). Siddiqui rejects religion and sees no role for it in struggles for women's rights, and also denounces the role of religion in fights against racism. In her view, a religious feminist cannot be fully supportive of women's rights because religion itself contravenes such rights. Siddiqui, her colleague Pragna Patel, and SBS more broadly, reject the role of any religious stakeholders in political deliberation and in public services, including religious organizations that are led by women. They insist that only secular women's organizations are legitimate representatives of all women, including religious women, and that the state should only listen to secular women's groups (Siddiqui 2008; see also Patel 2011a and 2011b; WAF and SBS 2007). The examples of WAF and SBS demonstrate the engagement by high-profile UKbased secular feminist organizations in discursive processes of Othering, in which religious women are marked as different from, and inferior to, secular women. Their discursive acts of Othering articulate a hard feminist secular position which in effect authorizes the repression of religious subjects in democratic deliberation.

Similar processes of Othering of religious women are widespread in public discourses in Europe and are often legitimated by powerful stakeholders. An example is the European 
Women's Lobby (EWL), an international women's umbrella organization founded in 1990 which represents more than two thousand women's organizations from European countries. Its goal is to promote gender equality and women's rights within the European Union. In 2006, it published its 'Religion and Women's Human Rights Position Paper of the European Women's Lobby' (hereinafter EWL 2006) due to concerns about the alleged influence of religious discourse on European governments' policies on gender equality and women's rights. Similar to the position declared by WAF, the EWL states that it considers religion as a private matter, and that religion may have a progressive influence (EWL 2006, 2). However, the EWL Paper predominantly discusses religion in terms of the proposed harm it causes women, citing religion's control over women's lives including dress codes, participation in the public sphere, access to education, work and positions of religious authority, the ability to marry and have children by choice, divorce rights, and sexuality. The EWL also discusses religion as a threat when it endorses women's roles as 'wife, mother and housewife as the ideal' (EWL 2006, 1). The only route to religious women's emancipation is via labour market participation and economic independence. Noting that religious freedom is 'an essential human right', the EWL nonetheless foregrounds a wide range of practices as rooted in religion and declares that religious freedom has to yield to the priority of gender equality and women's rights, regardless of whether women have consented or not to these practices (EWL 2006, 3). In this hard form of feminist secular discourse, religious women are represented as victims and as lacking in agency. By representing religious women as 'the apparently alldetermined other' (Pickering 2001, 74), the EWL's secular discourse in effect deprives religious women of the right to dignity and self-determination. Moreover, by singularly attributing all forms of discrimination that women may face to religion, any secular sources of such discrimination are silenced. 
The EWL Paper specifically endorses the Council of Europe's Parliamentary Assembly Resolution 1464 from 2005 which recognizes that religion plays an important role in the lives of many women in Europe but also declares that its 'influence is seldom benign' (Council of Europe 2005a, 1). ${ }^{\text {ii }}$ As does the EWL Paper, Resolution 1464 charges religion with upholding 'the role of wife, mother and housewife as the ideal', and claims that this ideal 'can be just as effective in achieving the subjection of women' as can very serious forms of violence (e.g., honour crimes, forced marriage and female genital mutilation) that are also assumed to be rooted in religion (C of E 2005a, 1). Multiple and diverse practices, some of which are common across populations in Europe (e.g., women staying at home to care for small children) and others that are extremely violent, are thus all attributed to religion. In this case, discursive representations of religious women as the Other, and as inferior to secular women, are forwarded by a transnational, democratic and deliberative institution, the Council of Europe (est. 1949), which represents forty-seven European states, twenty-eight of which are also members of the European Union.

Attached to Resolution 1464 are two further documents: a 'Report on Women and religion in Europe' (DOC 1670) and an 'Explanatory Memorandum' (Council of Europe 2005b), both authored by rapporteur Rosmarie Zaplf-Helbling, a Swiss parliamentary member of the Council of Europe from the Group of the European People's Party and a politician with feminist credentials. ${ }^{\text {iii }}$ The memorandum (rightly) notes that religion can be used to justify attacks on 'such vital human rights as the right to life, to bodily integrity, to freedom of movement and choice of partner' (Council of Europe 2005b, section C, 14). It goes further, however, in positing direct links between religion and a range of social practices, and in claiming that all of these (female genital mutilation, honour crimes, a lack of access to education and low labour market participation among women, and the wearing of headscarves) make religious women into victims. This discourse of Othering represents 
religious women as oppressed and inferior, and secular women as liberated and superior. While broadly acknowledging that there is 'general discrimination' against secular women in Europe, specific forms of discrimination experienced by secular women are silenced in the memorandum, including ubiquitous forms such as 'economic inequality, glass ceilings, misogyny and domestic violence' (Scott 2018, 182). Notably, Islamic headscarves are singled out as 'the most widespread - and visible - problem in Europe' (Council of Europe 2005b, section C, 20), with the author, Zaplf-Helbling, noting that 'The reason why I find it so difficult to respect the headscarf as a religious symbol like any other is that there is so much baggage that comes with it, a sense of submission to the control by men of a girl or woman's destiny and the way she leads her life' (ibid., section C, 23). The headscarf is here presented as a signifier of submission, which makes it difficult to extend the right to self-autonomy and dignity to women who wear the headscarf. This discourse specifically marks ethnic minority and immigrant Muslim women as 'deprived of individual agency’ (Scott 2018, 182) and constructs them as the non-white, non-European, non-secular Other. Through the discursive deployment of such techniques of Othering, white, secular European women are constructed at one and the same time as superior and as neutral arbiters of women's collective interests. The next section continues to examine the relationship between religion, secularism and feminism via a discussion of findings from interviews with religious women on gender equality, women's movements and feminism.

Non-feminist religious women's discursive representations of gender equality, women's movements and feminism

How do religious women view gender equality, women's movements and feminism? In a recent book, Beatrice Halsaa and I discuss the views of thirty-one Christian and thirty Muslim women living in Madrid, Spain; Oslo, Norway; and Leicestershire, United Kingdom 
(Nyhagen and Halsaa, 2016). ${ }^{\text {iv }}$ The participants were recruited from churches and mosques and included Catholic, Lutheran, Anglican, Pentecostal, Shia and Sunni women. Most of the Christians (27 out of 31) were from ethnic majority backgrounds and most of the Muslims ( 28 out of 30 ) were from ethnic minority backgrounds. The women were either in paid partor full-time employment, homemakers, retired, or in higher education. Their ages ranged from eighteen to seventy-five, with most aged between thirty and sixty. Below, differences among the women pertaining to their religious traditions (Christianity versus Islam) and country of origin are noted where relevant. Age was not identified as having a notable impact across the sample. The research interviews provide discursive representations of these women's views on gender equality, women's movements and feminism, and as such offer insights into current contestations of feminism, secularism and religion.

Four different discursive representations of gender equality were found to be present within the interviews with Christian and Muslim women (Nyhagen and Halsaa, 2016). In the first discourse, articulated by a small group of the women (about eight, mostly Pentecostals, mainly residing in Spain), gender equality was seen as impossible due to God-given prescriptions. These interviewees talked about women and men as having equal worth, but they also viewed men as superior to women in terms of their capabilities for rational thinking and physical work. Some also afforded men greater role in spiritual matters and a leading role in the family household. In this discursive representation, gender equality is denied and thus disassociated from religion. In the second discourse, articulated by an even smaller group of women (about four, from varying faith groups, residing in different countries), gender equality was viewed as differentiation but without hierarchy, and men and women were perceived as fundamentally different due to their biological and/or social roles. Yet, women and men were afforded equal status, and their different gender roles were seen as complementary. Moreover, women were seen as capable of inhabiting positions of power in 
the public sphere. In this discursive representation, gender equality (as differentiation without hierarchy) is compatible with religion. The third discourse, articulated by roughly a third of the interviewees (mostly Muslims residing in Norway, but also Muslims in the UK and Spain, as well as a few Pentecostals), emphasised gender differentiation in the home but not in the public sphere. Women's main responsibility was caring and housework, with men having a duty to provide, and these gender roles were seen as God-given. However, women could also have paid work, thus signalling that gender relations are both different and equal at the same time. This discursive representation signals that a limited notion of gender equality (pertaining to the public sphere) is compatible with religion. Half of the interviewees (twenty Christians, mostly from majority churches (Lutheran, Anglican, Catholic) in the three countries but also some Pentecostals; and ten Sunni and Shia Muslims from the three countries) engaged a fourth and final discourse about gender equality as embracing difference, where women were perceived as both different and equal. Here, women and men were seen as having equal opportunities both in the household and in the spheres of politics, work and civil society, regardless of any biological and/or socially produced gender differences. These interviewees argued that a person's assigned gender should not be a hindrance to their taking up any role they were capable of or had a yearning for. In this discursive representation, gender equality is portrayed as an expectation in religious women's lives. Overall, the variety of discursive representations of gender equality imparted by the interviewees demonstrates that religious women reflect on and negotiate gender relations within a complex nexus of individual agency, religious subjectivities and structural conditions. Most of the discourses indicated that at least some form of gender equality is compatible with religion, thus suggesting that constructed secular and religious boundaries and differences between women are malleable. 
Turning now to discursive representations of women's movements found in the interviews with Christian and Muslim women, the overall dominant discourse was one of embracement (either strong or conditional) of women's movements (Nyhagen and Halsaa, 2016), suggesting a further potential for the deconstruction of boundaries between religious and secular women. However, some discursive representations of women's movements also suggested more fortified boundaries between religious and secular women.

Overall, a majority of the interviewed Christian and Muslim women from Norway, Spain and the UK imparted positive views on women's movements and embraced their contributions to women's rights and gender equality, including women's right to vote and to education, women's increasing involvement in paid employment, and campaigns for equal pay. Women's movement claims-making regarding abortion, contraception, sexuality, divorce, child care and domestic work were, however, much less mentioned and, if at all, from either a 'mixed feelings' or a negative point of view. While the dominant discursive representation of women's movements among the interviewees was one of embracement (either strong or contingent), references to any positive impact of women's movements tended to invoke the past and implicitly conveyed that such movements were no longer needed to secure women's rights and gender equality. Very few had ever participated in women's movement activism. However, the women acknowledged the importance that women's movements have had for women's rights and societal opportunities more broadly, with some also suggesting a more direct impact on their own rights and opportunities in terms of education, work, settling where they wanted and also living alone. These discursive representations signal some degree of compatibility between women's movement activism and religion. There were more Muslims than Christians, and more residing in Spain than in Norway and the UK, among those who put forward a weaker embracement of 'conditional recognition' which relegated women's movement achievements to the past and portrayed movement claims about marriage 
and reproduction (e.g., sexuality, abortion and divorce) as too radical. A further, tiny and mixed group of Christian and Muslim interviewees, two of whom resided in Spain, rejected women's movements. They imparted explicitly negative representations of women's movements and objected to women's activism by portraying it as 'extreme' or suggesting that women should instead concentrate their energies on motherhood and the education of their children. In this representation, women's movement activism is irrelevant for, and even an antithesis to, religion.

The discourses about feminism found among the Christian and Muslim women interviewees included an 'anti-feminism' discourse, a 'pro-feminism' discourse, a 'mixed feelings' discourse and a 'post-colonial' discourse (Nyhagen and Halsaa, 2016). Somewhat surprisingly, an anti-feminist discourse was the most prominent among a majority of participants. While these interviewees did not explicitly link feminism with either religion or secularism, feminism was implicitly understood as associated with forces external to religion. The dominant anti-feminist discourse was present among both Christian and Muslim interviewees in all three countries, but more so in Spain and the UK than in Norway, and most often among Pentecostals. In this discourse, feminism was represented as 'extreme', 'excessive' and 'immoderate', and as something that had to be rejected. Feminist issues and strategies, as well as individual feminist women, were portrayed as 'extreme'. 'Extreme' issues included abortion, divorce, lesbian rights and 'unlimited' or 'exaggerated' claims to gender equality. The interviewees were also very critical of alleged feminist practices such as bra-burning, women positioning themselves as against men (or even hating men), and child neglect. They perceived feminists as wanting to 'put down men' or to 'dominate' men, and characterized feminists as 'hard' and 'power-seeking', 'unwomanly' women' and 'lesbians'. Moreover, feminists were portrayed as self-centred, egoistic women who care more about themselves than about their children and husbands; they were seen as lacking in generosity 
and as putting their own interests before that of families and society. Feminists were also portrayed as career-oriented and 'money-seeking' and as lacking in morality due to their alleged child neglect, their selfish break-up of families due to divorce, and their dominant attitude towards men. This anti-feminist discourse positioned feminism as antithetical to the interviewed women's own religiously based norms and identities. The interviewees forefronted love and care for others including family members, friends and neighbours, rather than individual autonomy. They emphasised gender roles in the family and beyond as different but equal; the complementarity of women and men, and valuing and respecting gender differences. For many of the participants, motherhood was their most important task. These positive sounding values and practices differed greatly from the negative values associated with feminist women. A picture of harmony and peace between women and men was also invoked, rather than one of conflict and struggle. Women's own interests were portrayed as intimately connected with loyalty and commitment to the larger unit of the heterosexual family, rather than with any political claims-making based on women's identification and solidarity with other women. These discursive representations suggest that a majority of the interviewed religious women engaged in a discursive Othering of secular feminists, viewing them as a singular group, devoid of complexity, femininity, morality and caring qualities. This anti-feminist discourse resonates with broader, negative societal representations of feminism in media and elsewhere, as argued by Walby (2011), Redfern and Aune (2010) and Seedat (2013).

A 'mixed feelings' discourse about feminism was articulated by a few Muslim and Christian participants across the three countries. Resonating with the 'contingent recognition' discourse about women's movements, the mixed feelings discourse opened up for a broader interpretation of feminism, acknowledging its potential to contribute positively to the lives of all women, including religious women. In this discursive representation, feminist activism 
was not portrayed as selfish, but as contributing to the common good. Some interviewees suggested that, at times, feminist activism has to take an extreme or radical form in order to achieve societal impact, while others explicitly endorsed more moderate campaign strategies. Women who expressed a 'mixed feelings' discourse did not call themselves feminists, and portrayed 'feminism' as too controversial and as representing 'negative' or 'extreme' tactics and issues. Nevertheless, these women voiced support for feminist demands that can give women increased opportunities. Overall, in the interviewed women's discursive representations, feminism was intimately linked with an individual-oriented, equal rightsbased version of feminism, concerned with liberating women from family and domestic work. While most interviewees wanted women to be recognised as having equal worth with men, they also noted the central importance of motherhood, family relations and gender differences to their own lives as religious women. These interests were represented as different from, rather than as overlapping with, feminist interests.

Pro-feminist and post-colonial feminist discourses were expressed by less than a handful of all the interviewed Christian and Muslim women. This may be reflective of the adopted recruitment strategy, in which women were recruited from mosques and churches, rather than from religious women's organisations or academic activist circles. A Christian interviewee from Norway, for example, said she would call herself a feminist because she wanted all women to have a voice and for women to be of equal worth and equal to men. A Muslim participant, also from Norway, expressed resentment towards what she saw as the paternalism and 'Othering of Muslim women by Western white and middle-class feminists who want to 'rescue' or 'save' Muslim women from their alleged oppression, including their wearing of the headscarf. She also pointed out that women who wear a headscarf can be a feminist. 


\section{Deconstructing the Othering of Feminism, Secularism and Religion}

In this article I have problematized the relationship between feminism, secularism and religion in the West by interrogating scholarly and political statements from a range of secular feminist stakeholders and by analyzing research interviews with Christian and Muslim women. As stated above, the context in which discursive representations are uttered, in what ways, and by whom, is important, not least because different stakeholders are differently situated in relation to power and powerlessness (Kitzinger and Wilkinson, 1996). Moreover, particular representations may align and resonate with, or deviate from, hegemonic discourses. Whilst recognizing that secular feminists and religious women may be situated differently in relation to 'multiple intersecting forms of power and powerlessness' (ibid., 16), the aim of my analysis of a purposeful selection of discursive representations has been relatively modest: to 'destabilize' and 'interrupt' narratives of Othering (ibid., 10). Throughout the discussion, I have demonstrated that secular and religious women use discursive strategies of Othering to demarcate differences and construct boundaries between different groups of women. Such discursive representations of the Other are based on binaries between feminism and religion, and between secularism and religion. These binaries serve to create differences between feminist secular and non-feminist religious subjects, or between us and them, where 'we' refers to superior, 'uniquely individual' women and 'they' refer to inferior, 'all-determined' women (Pickering, 2001: 74).

As evidenced in a range of Western feminist discourses about religion and gender, including writings by the academic radical feminist Sheila Jeffreys, feminist women's organizations such as Women Against Fundamentalism, Southall Black Sisters and the European Women's Lobby, and parliamentarians in the Council of Europe, religious women are depicted as victims of oppression, and religion itself is inextricably bound up with backwardness and gender inequality. By placing religious women outside the boundary of emancipated 'women 
like us', hard secular feminists signal a strict demarcation between religion and secularism which relegates religious women to a position of ignorance and victimhood. A further effect is that religious feminists and religious women who engage in gender equal practices are silenced.

I have also shown that religious women may engage in similar processes of discursive Othering by associating feminism with man-hating, political lesbianism, materialism, selfishness and secularism. The interviewed Christian and Muslim women's discursive representations construct feminists as different from the family-oriented, maternal and caring, non-materialist and unselfish, heterosexual and man-loving attributes of religious women. However, many of the interviewed religious women reflected on and negotiated gender equality in their own everyday lives, which signals unstable and porous boundaries between religion and feminism. A majority of the interviewed women also embraced women's movements and recognized their positive impact on women's status and rights in society. This also indicates a certain permeability of the constructed boundaries between religion and feminism. Nevertheless, the interviewed women's anti-feminism discourse silences the variety and complexity of feminist ideologies that support gender equality, including those that assign positive roles and responsibilities for men. Moreover, their representations of feminism resonate with more widespread public discourses about feminism as 'extreme' (Walby 2011).

In conclusion, the discursive forms of Othering discussed herein represent the Other (be it 'religious women' or 'secular feminists') as unitary and static, devoid of complexity, struggle and change. In turn, they hinder mutual understanding between secular and religious women and undermine the potential for joint strategic political alliances in the fight for gender equality. While evidence of joint mobilization between secular and religious women around common causes ranging from women's rights to alliances against head scarf bans are 
emerging (see Aksoy 2015, Van den Brandt 2015), extant knowledge is limited. Further empirical studies are needed of how secular and religious women represent and contest the relationship between feminism, secularism and religion.

\footnotetext{
${ }^{i}$ Elsewhere (Nyhagen 2017) I argue that only the soft secular feminist position is compatible with the 'lived religion' perspective in the sociology of religion.

ii The EWL encourages 'EU Member States to: Implement the Council of Europe Resolution immediately (EWL 2006, 4; original in italics).

iii In July 2015, twenty-five experts on religion and gender issued the 'Coventry Statement on the Parliamentary Assembly of the Council of Europe Resolution 1464 "Women and Religion in Europe" in response to Resolution 1464 (see Nyhagen 2017, 505-506).

${ }^{\text {iv }}$ For a more detailed description of sampling and recruitment strategies and the actual sample of interviewed Christian and Muslim women, see Nyhagen and Halsaa 2016, 23-27.
}

\section{References}

Aksoy, Hurcan Ash. 2015. "Invigorating democracy in Turkey: The agency of organized Islamist women”. Politics \& Gender 11, no. 1: 146-170.

Aune, Kristin. 2014. "Feminist Spirituality as Lived Religion: How UK Feminists forge Religio-spiritual Lives”. Gender \& Society 29, no. 1: 122-145.

Aune, Kristin and Line Nyhagen. 2016. "Religion, Politics and Gender”. In Routledge Handbook of Religion and Politics, edited by Jeffrey Haynes, 335-351. New York: Routledge.

Aune, Kristin, Sonya Sharma and Giselle Vincett. 2008. Women and Religion in the West. Challenging Secularization. Aldershot: Ashgate.

Balchin, Cassandra. 2014. "Making myself through difference". In Women Against Fundamentalism. Stories of Dissent and Solidarity, edited by Sukhwant Dhaliwal and Nira Yuval-Davis, 210-223. London: Lawrence andte Wishart.

Beckford, James A. 2003. Social Theory and Religion. Cambridge: Cambridge University Press. 
Braidotti, Rosi. 2008. "In Spite of the Times: The Postsecular Turn in Feminism". Theory, Culture \& Society 25, no. 6: 1-24.

Braude, Ann. 2001. Radical Spirits: Spiritualism and Women's Rights in Nineteenth Century America. $2^{\text {nd }}$ ed. Bloomington: Indiana University Press.

Braude, Ann. 2004. “A Religious Feminist - Who Can Find Her? Historiographical Challenges from the national Organization for Women". The Journal of Religion 84, no. 4: $555-572$.

Cady, Linell E. and Tracy Fessenden. 2013. Religion, the Secular, and the Politics of Sexual Difference. New York: Columbia University Press.

Castelli, Elizabeth A. 2001. "Women, Gender and Religion: Troubling Categories and Transforming Knowledge”. In Women, Gender and Religion: A Reader, edited by Elizabeth A. Castelli, 3-25. Basingstoke: Palgrave.

C of E. 2005a. Council of Europe. Resolution 1464 (2005) Women and Religion in Europe. Council of Europe: Parliamentary Assembly.

C of E. 2005b. Council of Europe. Women and Religion in Europe. Doc. 10670. Report. Council of Europe: Parliamentary Assembly.

Dhaliwal, Sukhwant and Nira Yuval-Davis N, eds. 2014. Women Against Fundamentalism: Stories of Dissent and Solidarity. London: Lawrence and Wishart.

EWL. 2006. Religion and Women's Human Rights: Position Paper of the European Women's Lobby. Adopted 27 May 2006. Available at: http://www.womenlobby.org/Religionand-Women-s-Human-Rights-May-2006 [accessed 16 August 2018].

Ferree, Myra Marx. 2006. “Globalization and Feminism. Opportunities and obstacles for activism in the global arena". In Global Feminism: Transnational Women's Activism, Organizing and Human Rights, edited by Myra Marx Ferree and Aili Mari Tripp, 3-23. New York: New York University Press. 
Fraser, Nancy. 2007. "Feminist Politics in the Age of Recognition: A Two-

Dimensional Approach to Gender Justice”. Studies in Social Justice 1, no. 1: 23-35.

Hall, Stuart (1997). 'The Spectacle of 'The Other', In Representation: Cultural Representations and Signifying Practices, edited by Stuart Hall, 223-279. London: Sage.

Jakobsen, Janet R. and Ann Pellegrini, eds. 2008. Secularisms. Durham: Duke University Press.

Jeffreys, Sheila. 2012. Man's Dominion. The Rise of Religion and the Eclipse of Women's Rights. London: Routledge.

Jeffreys, Sheila. 2011. "Desecularisation and Sexual Equality”. The British Journal of Politics and International Relations 13: 364-382.

King, Ursula. 2004. "Christianity and Feminism: Do They Need Each Other?” International Journal for the Study of the Christian Church 4, no. 3: 194-206.

Kitzinger, Celia and Sue Wilkinson (1996). 'Theorizing Representing the Other'. In Representing the Other. A Feminism \& Psychology Reader, edited by Sue Wilkinson and Celia Kitzinger, 1-32. London: Sage.

Kosmin, Barry A. 2007. “Contemporary Secularity and Secularism”. In Secularism \& Secularity: Contemporary International Perspectives, edited by Barry A. Kosmin and Ariela Keysar, 1-13. Hartford, CT: Institute for the Study of Secularism in Society and Culture.

Laborde, Cecile. 2017. Liberalism's Religion. Cambridge, MA: Harvard University Press.

Llewellyn, Dawn and Marta Trzebiatowska. 2013 "Secular and Religious Feminisms: A Future of Disconnection?" Feminist Theology 21, no 3: 244-258.

Mahmood, Saba. 2005. Politics of Piety: The Islamic Revival and the Feminist Subject. Chicago: University of Chicago Press. 
McFadden, Margareth H. 1999. Golden Cables of Sympathy: The Transatlantic Sources of Nineteenth-Century Feminism. Lexington: The University Press of Kentucky.

Nussbaum, Martha C. 2012. The New Religious Intolerance. Overcoming the Politics of Fear in an Anxious Age. Cambridge, MA: The Belknap Press of Harvard University Press.

Nussbaum, Martha C. 1999. “A plea for difficulty”. In Is Multiculturalism Bad for Women? Susan Moller Okin with Respondents, edited by Joshua Cohen, Matthew Howard and Martha C. Nussbaum, 105-114. Princeton: Princeton University Press.

Nyhagen Line. 2017. "The Lived Religion Approach in the Sociology of Religion and its Implications for Secular Feminist Analyses of Religion”. Social Compass 64, no. 4: 495511.

Nyhagen, Line and Beatrice Halsaa. 2016. Religion, Gender and Citizenship: Women of Faith, Gender Equality and Feminism. Basingstoke: Palgrave Macmillan.

Nyhagen, Line and Beatrice Halsaa. 2012. Majority-Minority Relations in Contemporary Women's Movements: Strategic Sisterhood. Basingstoke: Palgrave Macmillan.

Nyhagen Predelli, Line. 2012. "Recognising place, space and nation in researching women's movements: FEMCIT”. Women's Studies International Forum 35: 141-143.

Offen, Karen. 1988. "Defining feminism: A comparative historical approach”. Signs 14, no. 1: 119-157.

Okin, Susan Moller. 1999. Is Multiculturalism Bad for Women? Princeton: Princeton University Press.

Patel, Pragna. 2011a. "Cohesion, Multi-faithism and the Erosion of Secular Spaces in the UK: Implications for the Human Rights of Minority Women". IDS Bulletin 42, no. 1: 2640. 
Patel, Pragna. 2011b. "Women migrants and faith organisations: changing regimes of gender, religion and race in London”. Feminist Review 97: 142-150.

Pearson, Ruth. 2014. "Linking the local with the global: the legacy of migrant grandparents". In Women Against Fundamentalism. Stories of Dissent and Solidarity, edited by Sukhwant Dhaliwal and Nira Yuval-Davis, 99-112. London: Lawrence and Wishart.

Pew Research Center. 2016. The Gender Gap in Religion Around the World. Availabe at: http://www.pewforum.org/2016/03/22/the-gender-gap-in-religion-around-the-world/

Pickering, Michael (2001). Stereotyping: The Politics of Representation. Basingstoke: Palgrave Macmillan.

Phillips, Anne. 2016. “Religion: Ally, Threat, or Just Religion?” In Religion, Secularism, \& Constitutional Democracy, edited by Jean L. Cohen and Cecile Laborde, eds., 47-65. New York: Columbia University Press.

Plaskow, Judith. 1990. Standing Again at Sinai: Judaism for a Feminist Perspective. San Francisco: Harper \& Row.

Redfern, Catherine and Kristin Aune. 2010. Reclaiming the F Word. The new feminist movement. London: Zed books.

Reilly, Niamh. 2017. "Recasting secular thinking for emancipatory feminist practice". Social Compass 64, no. 4: 481-494.

Scott, Joan W. 2018. Sex \& Secularism. Princeton: Princeton University Press.

Siddiqui, Hannana. 1991. "Review essay: Winning freedoms". Feminist Review 37: $78-83$.

Siddiqui, Hannana. 2008. "Making the Grade? Meeting the Challenge of Tackling Violence Against Ethnic Minority Women”. In Seeing Double. Race and gender in ethnic minority women's lives, edited by Zohra Moosa, 39-62. London: Fawcett. 
Taylor, Charles. 2011. "Why We Need A Radical Redefinition of Secularism”. In The Power of Religion in the Public Sphere, edited by Eduardo Mendieta and Jonathan Vanantwerpen, 34-59. New York: Columbia University Press.

Van den Brandt, Nella. 2015. "Feminist practice and solidarity in secular societies: Case studies on feminists crossing religious-secular divides in politics and practice in Antwerp, Belgium". Social Movement Studies 14, no. 4: 493-508.

Wadud, Amina. 1999. Qur'an and Woman. Rereading the Sacred Text from a Woman's Perspective. New York: Oxford University Press.

WAF. 1996. Women Against Fundamentalism. Journal no. 8. London: Women Against Fundamentalism.

WAF and SBS. 2007. Commission on Integration and Cohesion: Submission by Women Against Fundamentalisms and Southall Black Sisters. January 2007. Available at: http://womenagainstfundamentalism.org/?page_id=12 [accessed 16 August 2018].

Walby, Sylvia. 2011. The Future of Feminism. Cambridge: Polity.

Woodhead, Linda. 2013. "Liberal religion and illiberal secularism”. In Religion in a liberal state, edited by Gavin D’Costa, Malcolm Evans, Tariq Modood and Julian Rivers, 93116. Cambridge: Cambridge University Press.

Žarkov, Dubravka. 2015. "Reflecting on faith and feminism”. European Journal of Women's Studies 22, no. 1: 3-6.

Zwissler, Laurel (2012). 'Feminism and Religion: Intersections Between Western Activism, Theology and Theory'. Religion Compass 6/7: 354-368. 